\title{
Twelve EU Countries on the Eastern Flank of NATO: What about Ukraine?
}

\author{
Przemysław Żurawski vel Grajewski \\ University of Lodz, Poland
}

\begin{abstract}
The Trimarium Initiative (TI) is a platform for co-operation of twelve central and eastern European (CEE) countries of the eastern flank of the European Union (EU), introduced by Poland and Croatia in 2015. The TI is based on member co-operation in the development of transport and communication, energy, raw materials (gas and oil) transfer infrastructure, and digitization. The region is an important and rapidly growing market, and the TI goal is to boost economic cooperation among these twelve countries. Ukraine is not an EU member state, so it cannot be a full member of the TI; however, several TI infrastructural projects are open to Ukrainian companies. As Russia's aggressive energy policy impacts Poland, Ukraine, the Baltic states, Scandinavia, and Slovakia, the TI has a potential to meet this challenge. Transport and communication and energy transit infrastructure are promising areas of co-operation among TI countries and Ukraine. U.S. support has added optimism and prestige to the initiative.
\end{abstract}

Keywords: Trimarium, Ukraine, Poland, infrastructure, transport, communication, energy, digitization, European Union.

INTRODUCTION 1

$\mathbf{T}$ he Trimarium Initiative (TI) (or Three Seas Initiative) has provoked much misunderstanding-propaganda that shows it in an anti-EU light and exaggerates its scope of interest, which involves infrastructural developments in the region, not military or political integration. The TI concept is often confused with the Intermarium concept (an alliance among central and eastern European countries first introduced by Adam Jerzy Czartoryski in 1830s and proposed by Poland to the neighbours in the region as a political practice between 1920 and 1938. Its first attempt was the Polish-Ukrainian alliance of April 1920 against the Bolshevik Russia. As the Trimarium Initiative is often misunderstood, this paper describes the goals of the TI and the projects that have been undertaken to achieve them (Gizicki). It also draws attention to the largest country of the region-

\footnotetext{
${ }^{1}$ This article was finalized in 2019 and reflects events up to that date, with only minor updates concerning the current situation.
} 
Ukraine-which cannot join the TI because it is not a member of the European Union. Poland, the second-largest country in the region and the first in TI (and the initiator of the Trimarium idea), has shown a longstanding interest in bringing Ukraine to the West. Polish foreign policy is active in including Ukraine in practical, economical functions of the TI, although it is not aimed at the formal inclusion of the country to the initiative and cannot offer Ukraine the perspective of the full membership in it. The reason for this is neither a mystery nor a symbol of Poland's allegedly changing foreign policy priorities. Ukraine is and will remain an important partner in all Polish regional policy initiatives. Still, effectiveness matters and for policy to be effective, it must be based not on declarations but on tangible achievements. TI, in order to survive and enjoy a sustainable support of all its twelve member states, must remain an inter-EU body. As long as Ukraine is not the EU member state, it is welcomed as a partner but not as a TI member country. In fact, it is the development of infrastructure that really matters and not the formal flags under which the roads and pipelines connecting Poland to Ukraine are constructed. There are many forums for co-operation between Ukraine and central and eastern European countries, including the Visegrád+ Eastern Partnership and the UkraineNATO Commission, so the creation of yet another such partnership is not crucial. But the goal of both Ukraine and Poland is still to move Ukraine to the West, far away from Moscow.

This article describes the history of the Trimarium Initiative (TI) and explains the character of the project. Prior to delving into the legal basis for Ukrainian involvement in TI, the actual dimension of the TI co-operation is analyzed, especially in the context of its historical predecessor-the Intermarium. The core sections are devoted to the goals and projects of the TI-namely, transport, energy infrastructure, and digitization. At the end, the article focuses on the dimensions of possible Ukrainian co-operation and summarizes the Ukrainian perspective of the TI.

\section{HistoRY OF THE TRIMARIUM PROJECT}

The Trimarium Initiative is a forum for infrastructure co-operation among twelve central European EU member states: Austria, Bulgaria, Croatia, Czechia, Estonia, Hungary, Latvia, Lithuania, Poland, Romania, Slovakia, and Slovenia. The combined area of the states in question constitutes one-third of the territory of the European Union and is inhabited by nearly 112 million people; its combined GDP is $\$ 3.3$ trillion (Brzeziński and Koranyi; see also Piotr Eberhardt; Zbińkowski 109). The region enjoys sustainable economic growth and a limited scale of unemployment that continues to fall ("Trójmorze"). At the time of this report, this constant economic growth has 
been halted by the COVID-19 pandemic; nevertheless, the region has managed this challenge far better than the western part of the EU and prognoses for its further development are optimistic (European Economic Forecast 130-31; Gnauck; Charrel). The economic potential of the TI region within the EU is thus not negligible. The TI countries offer each other stable trade conditions, low political risk, personal and legal security to entrepreneurs and employees, geographical proximity (thereby lowering transportation costs), and consumers with relatively large and growing purchasing power who are not dispersed over a large territory-the last condition being unlike the situation in Russia. When factoring in the impact on regional development of the TI's infrastructure projects, the region could become a powerful and attractive market for the entire EU.

Poland, with its 38 million inhabitants, has a clear pro-Atlantic foreign policy based on close co-operation with the U.S., and Polish military have a presence (together with Canada) on NATO's eastern flank, in Latvia and in Romania. What is additionally crucial for the purpose of this research is the strong and stable Polish interest in Ukraine. ${ }^{2}$

The first informal meeting of the Trimarium states took place in New York on 29 September 2015; officially, the TI was launched as a PolishCroatian project by the presidents of Poland and Croatia, Andrzej Duda and Kolinda Grabar-Kitarović, respectively (Views and News; Sobczyk 58). Formalized at the first TI summit in Dubrovnik (25-26 August 2016), ${ }^{3}$ the initiative gained new momentum at its second summit in Warsaw (6-7 July 2017) (Żornaczuk; Kowal and Orzelska-Stączek 60-67; Zbińkowski 114-15), especially since it was combined with and supported by a visit from the U.S. president, Donald Trump, to that city (5-6 July 2017) ("Remarks by President"; "Poland: Trump Visit"). The summit was simultaneously accompanied by the Global Forum, ${ }^{4}$ which emphasized the transatlantic interest in the event. The main practical resolutions of the Warsaw TI summit were to create the Trimarium Business Forum and the "Joint Declaration" of the twelve TI member states ("Powołamy forum biznesowe państw Trójmorza"). The Declaration defines the provisions, goals, and principles of the group, and even though Ukraine is not mentioned, three of the provisions in the document determine the nature of future relations

\footnotetext{
2 For more on Polish-Ukrainian relations, see Żurawski vel Grajewski, The Eastern (66-117) and "Specyfika."

3 The Joint Statement on the Three Seas Initiative; "The Three Seas Initiative: Central and Eastern"; for more, see Kowal and Orzelska-Stączek 56-60 and Zbińkowski 11213.

4 The Global Forum was organized jointly by the Atlantic Council and the Polish Institute of International Affairs (a think-tank run by the Polish Ministry of Foreign Affairs). For more, see Global Forum 2017.
} 
between Ukraine and the TI: (1) openness to interested business entities from all over the world; (2) EU membership as a precondition for TI membership; and (3) in the long-term nature of the joint plans, invitation to Ukrainian companies to co-operate in all the projects launched within the TI ("President Duda").

The strong American support for the TI deepened the Romanian interest in the Trimarium Initiative (Milewski). The third TI summit was held in Bucharest on 17-18 September 2018 and resulted in two important decisions: the establishment of the Trimarium Fund as a common budgetary instrument and the acceptance of Germany as a permanent observer of the TI summits (Kowal and Orzelska-Stączek 67-74; Zbińkowski 115-16). The first decision turned the character of the initiative into an intergovernmental budgetary exercise. The fact that Germany was interested enough to ask for the membership in the TI (and finally to accept the status of a permanent observer) indicated that the TI was a serious institution in Europe, not just an "ephemeral short-lived phantasy of megalomaniac Poland." It also reduced the hostile propaganda of opponents who had deprecated the TI and implied that the TI had anti-EU or anti-German leanings. When the U.S. president supported the initiative during the 2017 TI summit in Warsaw, there were suggestions that Washington was eager to use the Trimarium to exert U.S. influence in the EU. A year later, both the EU and Germany decided that engagement was the best response, and the TI summit in Bucharest was attended not only by Jean-Claude Juncker, head of the European Commission, but also by Heiko Maas, Germany's foreign minister-who said Berlin was keen to join the club and to use it to build bridges between eastern and western Europe (Shotter). Germany's associated status in the initiative has substantially weakened the grounds for any further suspicions and accusations. ${ }^{5}$

\section{THE NATURE OF THE TRIMARIUM INITIATIVE}

The beginning of the TI project and its evolution comprise an example of constructive and functional international relations. For first few years the TI was mainly involved in high level political conferences among the presidents of the countries in question, to discuss important problems of the region and plans to mitigate them (Kowal and Orzelska-Stączek 85-86). Then that initial dimension evolved to tangible interests, real material, and financial decisions, passing from the world of words to the world of facts (OrzelskaStączek).

\footnotetext{
${ }^{5}$ For the German view on the TI, see Dahl.
} 
The project focused on three dimensions-transport infrastructure, energy infrastructure, and digitization, being economic in nature. The TI involved trade, service, and industrial co-operation, and the strengthening of cohesion among the states in NATO's eastern flank. Ultimately, the initiative intended to develop economic links and people-to-people contacts among CEE (central and east European) countries, and to include them in the process of European integration as active creators, not merely as passive recipients of ideas and projects conceived in the core EU states.

Except for Austria, all the other TI countries used to be provinces of former empires (Russian/Soviet, Habsburg, or German), and their infrastructure had developed according to the economic needs of the dominant nations, with their imperial capitals (St. Petersburg/Moscow, Vienna, and Berlin) as the transport hubs in the region. As a result, according to the European Commission, highway and railway journeys in the CEE countries take an average of two to four times longer than journeys of comparable distance in western Europe (Shotter).

All the states involved in the TI (except Austria) experienced Communism after World War II and have inherited a backward infrastructure. The European Single Market, to a large extent, is merely a "declared reality" in the region so far. The shortage of transport infrastructure prevents the countries in question from exploiting the potential of their respective markets. The TI is positioned to overcome that weakness. Thus, the Trimarium is a complement, not an alternative, to the EU (Szczerski 251). The TI is a vehicle to move the basic structure of European integration (the single market) from words to action.

The power of the Trimarium Initiative lies in its infrastructure and in the current limitation of its membership to EU member states. Although there is potential for wider co-operation, both geographically and thematically, in the region, the TI might sink under a burden of too many priorities and too many national initiatives. This is why Poland has not invited Ukraine, Croatia has not invited Bosnia-Hercegovina (in spite of its large Croat population), and Romania has not opened the door for Moldova. Co-operation with all those countries is possible, but first the EU framework must be fulfilled, not merely by plans and promises but by tangible initiatives among the twelve founding states. The participation of Scandinavian countries is desirable and logical-due to their EU membership, their geographical positions, and the added value they can bring to the TI (e.g., their prestige as "established" countries in the West, the quality of their state apparatus, their "networking capital"6 within the EU, high technology, and so on). Energy raw material

\footnotetext{
6 The term "network capital" is used to describe the political advantage that a state enjoys if it possesses loyal officials in numerous important functions within the structure of an international organization-in this case, the EU (Grosse 138-39).
} 
transit in the TI is focused on reducing the region's dependence on Russian gas (Zbińkowski 109-10; Sienkiewicz 146-48). If integrated within the TI, transport and communication combined with energy policy could minimalize the costs of the EU policy of decarbonization (for more, see: Bieliszczuk and Wąsiński).

\section{THE TRIMARIUM VERSUS THE INTERMARIUM}

The Polish interwar idea of the Intermarium was based on a vision of political and military co-operation between the CEE countries that were threatened by German and Soviet imperialism (Okulewicz; Cieplucha). Today the international milieu is substantially different, particularly given the American military presence on the ground, the existence of NATO and the EU, and the fact that Germany is now an allied democracy. On the other hand, the Russian challenge remains a factor in the region. Therefore, even though the Latin roots sound alike, the similarity of the names Trimarium and Intermarium should not mislead us.

The Trimarium is potentially geographically wider than the Intermarium was, since it is open not only to the countries situated between the Baltic, Adriatic, and Black Seas, but also to countries located around the Baltic Sea. It may include the Scandinavian states-which, as mentioned above, are not yet participants but are perceived as desirable and attractive potential partners by Poland and the Baltic states. Unlike the Intermarium, which was primarily intended as an answer to the military threat to the region and whose original backbone was the Polish-Ukrainian and PolishRomanian anti-Soviet alliances of 1920 and 1921, today's Trimarium is not about defence but about infrastructure.

Theoretically, there is potential for co-operation beyond infrastructure in the region. For example, the security dimension is a possible area of TI activity; another is co-operation to promote solutions in the EU that would meet the interests of TI countries. As the Trimarium Initiative is not about security (Żurawski vel Grajewski, "Trimarium" 16-19), rumours about security are merely theory (see Stępniewski 39-40). Nevertheless, it is true that some TI countries share the same views of the military dimension of international relations in the region, and-especially after 2014-share the same perception of the Russian threat. Regional integration for defence began at the November 2015 summit of NATO eastern flank countries that was convened at the initiative of Poland and Romania. At that summit, the "Bucharest 9" (B9) (Bulgaria, Czechia, Estonia, Hungary, Latvia, Lithuania, Poland, Romania, Slovakia) came into being. Given the context of Russian aggression in Ukraine, the B9 countries appealed to NATO to strengthen the alliance's eastern flank. B9 countries that shared common land or a maritime 
border with Russia (Baltic states, Poland, Romania, Bulgaria) made a formal request to NATO for troops on their soil, while those lucky not to have such a neighbour (Czechia, Hungary, Slovakia) offered the others political solidarity and support ("Joint Declaration on 'Allied Solidarity"'; see also "Nine Leaders"; Ioniță and Manea; Sobczyk 56-58). The requests were accepted (except for Bulgaria, given its location farther to the south) at the July 2016 NATO summit in Warsaw and implemented by mid-2017 ("Boosting NATO's Presence"). In 2018, there were 4,743 NATO troops on the alliance's eastern flank ("NATO's Enhanced Forward Presence").

The B9 countries proved to be an effective lobbying group within NATO. This function, however, has exhausted the potential for further pan-regional action in the security area. It is NATO that serves as a common defence structure in the region, and there is no need to repeat it with regional substructures. Austria-one of the TI's twelve countries-is not a NATO member state, while Croatia, Czechia, Hungary, Slovakia, and Slovenia are not eager to tighten the military links in the region. Therefore, to add a defence dimension to the TI would mean to undermine the common consent of the members and could weaken the alliance. The TI countries are aware of that, and neither Poland nor the countries on NATO's eastern flank (the Baltic states and Romania, who share a security policy priority with Poland) want to risk it. Poland and Romania are both leading B9 countries and important partners in the TI, and there is some hope that their co-operation can be combined to work with the EU and NATO to add security to the countries on NATO's eastern flank (Rotaru and Umland). All the B9 states are simultaneously members of the EU and of NATO, and almost all the TI member states (except for Austria) are NATO member states, too.

The same can be said about the future of the EU, whose members do not take a common position. The region is not politically homogenous, and one can hardly expect any far-reaching uniformity of position on issues debated in the EU (Gniazdowski). Countries in the Three Seas Initiative (except Austria) hope that the initiative will mitigate the reduction in EU cohesion funding that central Europe anticipates having to face in the next EU budget. This could result from Brexit (the withdrawal of Britain from the EU) and a shift in the EU's funding priorities that might be due to the immigration crisis and continuing problems with the eurozone (countries that have adopted the euro [€] as their primary currency), or from new ambitions, e.g., PESCO (Permanent Structured Cooperation), or simply from electoral pressure from citizens of the "old" EU member states (Shotter).

There is a common conviction that each new topic added to the TI will result in variable responses from member countries. However, work on each issue does not take place in complete isolation, and the success or failure of the group in one field will have an impact on its activity in other fields. TI countries must be realistic and must deliver success in one well-chosen field 
of activity before launching new initiatives or extending the original project to new dimensions.

\section{POLITICAL ASPECTS OF THE TRIMARIUM}

The Trimarium is not a political block and is not likely to turn into one in the foreseeable future. In some sense everything is political; still, the hope or the threat that the TI might be turned into a source of a political will is groundless, although it has been voiced frequently. Unlike the countries in the Intermarium and the Danubian Federation, countries in the TI do not aim to create a political or military bloc. Austrian support for Nord Stream 2 (offshore natural gas pipelines from Russia to Germany) (Gniazdowski 79), the nature of Hungarian relations with Russia (Héji 71-72), and Czech, Slovak, and Slovenian reluctance to participate in the Great Powers' (Germany and Russia) games in the region make any hope for further development of a political or military initiative groundless (Dahl 66). Austria, the Baltic States, Slovakia, and Slovenia belong to Euroland, while Bulgaria, Croatia, Czechia, Hungary, Poland, and Romania do not (Dobija). Bulgaria, Croatia, and Romania are not Schengen Zone member states yet. Just to mention the geographical extrema, it is not a mystery that Estonia and Bulgaria are very dissimilar countries (for more on the Bulgarian attitude toward the TI, see Siedlecka and Sułkowski; Czernicka). The twelve countries in the TI are too different; therefore, there will be no joint political interest and political will to unite Austria-the foreign minister of which (Karin Kneissl) invited Putin to her wedding party in 2018 (Eddy) - with Estonia, Latvia, Lithuania, Poland, and Romania-countries that keep ringing an alarm bell with regard to Russian imperial policy in the region (e.g., "Joint Statement by Estonia, Latvia, Lithuania, Poland and Romania").

There is a limit to common understanding of the Russian threat among the twelve member states of the TI. The Baltic states, Poland, and Romania are close or even unanimous in their perceptions of Russia's imperial policy, but one can hardly say that about Slovakia, where twenty-five percent of the electorate want to leave NATO and to reorient the country's foreign policy toward Russia (Dębiec and Groszkowski). Czechia shares no border with the post-Soviet area; all its neighbours are EU member states, and all except Austria are NATO member states. There are a lot of problems in HungarianRomanian and Hungarian-Slovak relations that prevent smooth cooperation in the region. Poland supports Ukraine-NATO co-operation (National Security 25), while Hungary's long-lasting position to block Ukraine-NATO co-operation has been changed only lately. This is the best example of the deep political divergences on fundamental issues that exist among the TI member states (Krekó and Szicherle; Szőcs). If we take into 
consideration the internal political dynamics in these countries, the situation appears even more complicated. The attitudes of these countries to Germany, to the EU, or to the US are also complex. Therefore, one can hardly expect the TI "block" to formulate a common policy in the foreseeable future.

\section{The Trimarium IS ABOUT InFRASTRUCTURE: “All RoAds LEAD to EURoPE”}

The economic potential of the countries involved in the Trimarium Initiative is not negligible. From a German perspective, the Polish market alone is more than twice that of Russia's, while the combined markets of the Visegrád Group ("V4": Czechia, Hungary, Poland, Slovakia) are greater than that of France. ${ }^{7}$ For years, Czechia was the second-largest market, after Germany, for Poland (€11.9 bn, or 8.4\%, of Poland's exports went to Czechia in 2015); in 2015, Czechia fell to third place, after the UK (€12.1 bn, or $8.5 \%$, of Poland's exports went to Czechia in 2016) and regained its position in 2017 (€13.29-€13.30 bn, or 8.0\%, of Poland's exports went to Czechia in 2017). In 2015, Polish exports to Hungary (€4.8 bn, or $2.7 \%$ ) were only slightly smaller than Polish exports to Russia (€5.1 bn, or 2.9\%), and Polish exports to Hungary in 2017 (€5.46 bn, or $2.6 \%$, to €6.93 bn, or 3\%) were also slightly smaller than Polish exports to Russia in 2017 (Rocznik Statystyczny Handlu Zagranicznego 2016 63, 116; Rocznik Statystyczny Handlu Zagranicznego 2018 55, 108-09). GDP growth in 2018 was 5.1\% in Poland ("Poland GDP"). GDP growth in 2017 was 7.3\% in Romania, 4.9\% in Estonia, 4.3\% in Czechia, and $4.0 \%$ in Hungary ("GDP Growth"). GDP growth makes this regional market the most rapidly growing market in the EU. A geographical proximity to the Mediterranean region makes Austria, Croatia, and Slovenia more interested in the Adriatic or Italian neighbourhoods and the transport and communication routes in that region (Żurawski vel Grajewski, "La nuova Europa").

\section{Goal Number 1: Transportation Infrastructure-Highways, Railways, Waterways}

Two main areas of co-operation in the infrastructural dimension of the Trimarium Initiative are transportation (rail lines and highways) and energy

\footnotetext{
${ }^{7}$ In 2016, German exports to Russia amounted to $€ 21.57$ bn, whereas those to Poland were $€ 54.79$ bn; German exports to France were $€ 101.3$ bn, and German exports to the V4 countries were $€ 128.2$ bn (with Poland at $€ 54.79$ bn, Czechia at $€ 38.2$ bn, Hungary at $€ 22.7 \mathrm{bn}$, and Slovakia at $€ 12.7 \mathrm{bn}$ ). Among other Trimarium states, Romania alone added $€ 13.57$ bn to the sum of German exports in 2016 (Foreign Trade 2).
} 
(liquid natural gas and oil terminals, gas and oil pipelines, gas storage facilities, gas interconnectors, electricity connections). Czechia, Hungary, Poland, Slovakia (V4) plus Croatia constitute the core countries in that field of co-operation. According to the declaration signed at the TI's Dubrovnik summit in 2016, the Trimarium countries aim to contribute to the construction of a Single European Market in the region, by strengthening sectoral co-operation in the fields mentioned above. After 1989, the original longer-term priority was the development of east-west transportation infrastructure. Citizens of central Europe wanted to become a part of western Europe again. That priority existed until the first great crisis of the EU in 2008-12 (resulting from the high debt of the countries in the southern flank of the EU-Greece, Italy, Spain, Portugal-plus Ireland). Since that time, the image of the West started to be much more complicated and nuanced. Today, the original task has been accomplished, and it is time to couple it with enhanced north-south connections. ${ }^{8}$ CEE countries' cohesion is crucial for Poland, a country situated at the crossroads of the two macroregions - the Baltic and the Danube. The infrastructure links between these regions, neglected in previous centuries by the empires that ruled the regions, should be strengthened to benefit the free nations of today.

The V4 and formats associated with it, such as V4+ (i.e., the V4 plus one external partner-usually Croatia, Romania, Slovenia, or Ukraine, with the last being the only non-EU partner) or the V4+NB8 (the V4 plus five Nordic and three Baltic states), have great potential for co-operation on bilateral and regional infrastructural projects in the transportation sector. The leading area for this kind of activity encompasses north-south rail lines and highways to connect the countries of the region and to spark further development of their economies. The most famous example is Via Carpatiathe planned highway that will start in the Greek city of Thessaloniki and end either at the Lithuanian port of Klaipeda or extend even further to the Estonian capital of Tallinn, with onward ferry connections to Helsinki in Finland. At its southern end, this highway will have branches across Bulgaria to Istanbul and to the Romanian Black Sea port of Constanţa. Another area ripe for this kind of co-operation is the Sudeten Mountains, where there is

\footnotetext{
8 Ovidiu Dranga, Romania's ambassador to Poland, said: "After joining the EU, we were looking primarily to the west in the process of integration. Now we are looking more to each other.... The Three Seas is about creating better connectivity in this north-south direction. Until now it was all east-west . . . . These three areastransport, digitalisation, and energy-are relevant not only for the region but for Europe in general. What we are aiming at is strategic resilience along the eastern frontier of NATO and the EU, as part of our contribution to Euro-Atlantic security and a stronger transatlantic link" (Shotter).
} 
room for potential bilateral Polish-Czech projects to construct road and rail links.

The plan to build Via Carpatia was initiated at a meeting of Polish, Lithuanian, Slovak, and Hungarian ministers of transport, attended by the Polish president Lech Kaczyński, in Łańcut on 27 October 2006. At this meeting, the Łańcut Declaration I on the extension of the TEN-T (TransEuropean Transport Networks) through the Via Carpathia was issued ("Łańcut Declaration"). On 22 October 2010, the initiative was joined by Romania, Bulgaria, and Greece, resulting in the "Via Carpatia Declaration," which acknowledged the earlier project and extended it to the south. The transportation ministers of the seven countries through which the route runs pledged to take all possible steps to incorporate it into the TEN-T along its entire length (Klaipeda-Kaunas-Białystok-Lublin-Rzeszów-KošiceMiskolc-Debrecen-Oradea-Lugoj-Calafat/Constanţa-Sofija/SvilengradThessaloniki), as part of an amendment to the EU law on trans-European transport networks (Poręba). Six years later, the group was joined by Turkey and Ukraine, and as a result the "Łańcut Declaration II" was signed in Warsaw on 3 March 2016 ("10 lat Deklaracji"; Ukielski). The decision was acknowledged and broadened on 17 April 2019, when "Łańcut Declaration III" was signed ("Wspólnym głosem"; "W Łańcucie podpisano"). ${ }^{9}$

The Polish section of Via Carpatia $(570 \mathrm{~km})$ runs along autoroute S19 and is planned to be completed by 2023 or 2024 ("Via Carpatia powinna być gotowa w 2024 r"). The estimated cost of the section-the investor is GDDKiA (General Management of the National Roads and Highways)-is $€ 30 \mathrm{bn}$. The S19, that runs from Barwinek on the Slovak border to Budzisko on the Lithuanian border, connects cities such as Rzeszów and Lublin. It is to be situated in the so called "Eastern Wall," which encompasses the eastern provinces of Poland ${ }^{10}$ that were part of the Russian Empire in the nineteenth

\footnotetext{
${ }^{9}$ For more information about the entire project, see Priority Interconnection Projects 2019 Status Report 83-87.

10 The term "eastern provinces of Poland" refers to the present eastern Polish provinces, not the pre-war provinces. Until 1915, when German and AustroHungarian armies occupied them, these provinces constituted the eastern gubernias of the Vistula Country. (The name "Polish Kingdom" was forbidden by Russians in the late nineteenth century, as was the name "Ukraine." Poland was renamed Privislinskii Krai, and Ukraine was called Malorossiia). Vistula Country was a backward part of Poland in comparison to the German part or the Austrian part. It was forbidden to teach children in the Polish language (which was the case under German rule, too, unlike under Austrian rule). Still, in the German part of Poland, education provided in the German language was obligatory and common, while in the Russian part of Poland only $30 \%$ of the population could read and write, and the entire administration was Russian. All cultural and political institutions of Poland were situated in Lviv under the Habsburg monarchy between 1867 and 1918
} 
century, and that bordered the USSR after World War II; their infrastructure was therefore especially neglected (Planowana infrastruktura Trójmorza).

The Via Carpatia, if treated as a "backbone," creates a temptation to be combined with some "ribs"-i.e., latitudinal connections to Ukraine (Rzeszów-Przemyśl-Lviv, Zamość-Volodymyr Volynskyi-Lutsk and LublinChełm-Kovel). Moreover, it is not only the Polish section of Via Carpatia that can be extended to Ukraine; connections are possible to the Slovak (via Mukachevo-Uzhhorod-Košice) and Hungarian (Mukachevo-Debrecen) segments. Ukraine is not a TI member state, yet nobody is forbidding its transborder infrastructural co-operation with the TI countries. On the contrary, such co-operation will encourage steps to achieve consistency of the infrastructure in the region and make such infrastructure complete. The success of the Kyiv-Lviv-Przemyśl rail connection opened by Ukrzaliznytsia (a Ukrainian Railways national corporation) in December 2016 and upgraded in August 2017 with additional trains-the Kovel-Chełm, launched 12 June 2017, and Odesa-Przemyśl, launched 10 December 2017suggests a potential for additional co-operation in the region (Gojke; "Druga para pociągów"; Janduła; Szymajda). These examples could be replicated elsewhere. A new rail service along the routes Wrocław-Kraków-PrzemyślLviv-Ternopil-Khmelnytskyi-Vinnytsia-Kyiv and Warsaw-Lublin-ChełmKovel-Korosten-Kyiv would reduce traffic at the overloaded PolishUkrainian road border crossings; this problem has become even more urgent since visa-free travel for Ukrainians to the EU began in June 2017. Local trains on the routes Lublin-Chełm-Kovel-Rivne-Zhytomyr and Przemyśl-Lviv-Ivano-Frankivsk-Chernivtsi would also help to reduce border congestion and could be combined in a common transport and communication system with the TI projects. To base the gauge of new train tracks on the European standard track gauge instead of the Russian track gauge should be considered.

because Warsaw was under Russian rule without any autonomy and with almost permanent martial law between 1861 and 1914. In the years 1918-39, the Polish provinces constituted the central part of Poland. It was Polish governmental policy to do its best to develop these provinces, including state sponsored industrialization, as the military industry was situated there for geostrategic reasons. After 1945, these provinces became the eastern borderland of Poland, and after 1989, while bordering Soviet or post-Soviet territories, they have attracted far less investment and interest than western provinces of Poland and are commonly known in Poland as the "Eastern Wall" - a synonym for "underdevelopment." 
Figure 1. Via Carpatia and its latitudinal branches to Istambul, Constanţa, and Ukraine. ${ }^{11}$

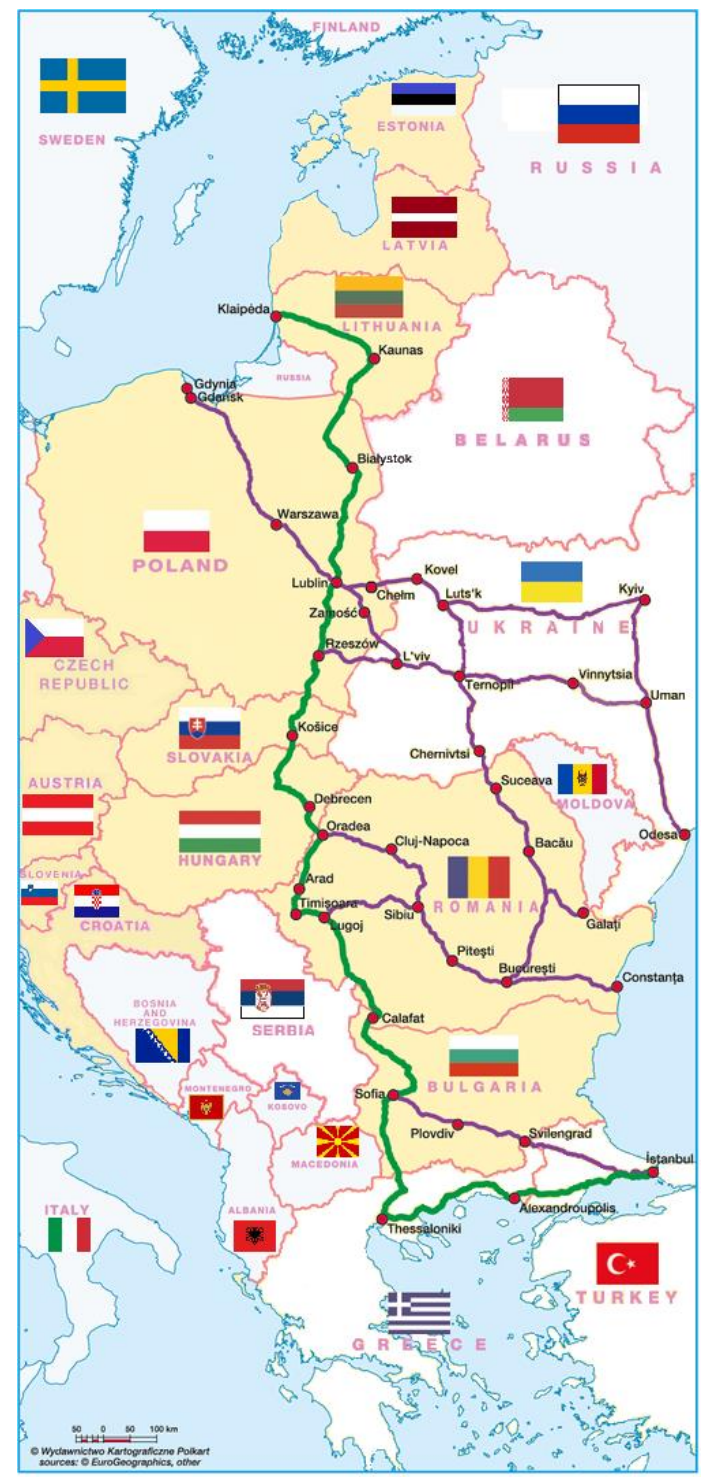

11 Ministerstwo Infrastruktury, Twitter, 6 July 2017, https://twitter.com/MI_GOV_PL/status/882918581712846848?s=20. Accessed 7 June 2021.

(C) 2021 East/West: Journal of Ukrainian Studies (ewjus.com) ISSN 2292-7956

Volume VIII, No. 2 (2021) 
Via Baltica is a project of the same nature as Via Carpatia. Via Baltica is a part of Branch B of the first pan-European transport corridor, partly based on European Route E 67 (Prague-Helsinki). The project has been included in the TEN-T program (see "Transeuropejska sieć transportowa"; "Infrastructure and Investment"). Its planned overall length within the Trimarium system is ca. $1,000 \mathrm{~km}$, and it connects Warsaw to Helsinki. It is to be an electric railway with European rail width. ${ }^{12}$ The plan is to complete the Warsaw-Helsinki section by 2026, and the $91 \mathrm{~km}$ Polish section by 2023 (51 km in 2021, $24.1 \mathrm{~km}$ in 2022, and the rest in 2023) ("Via Baltica"). The work is ongoing in Poland, and the railway between Warsaw and Białystok is being modernized to upgrade the speed capacity of the line to $160 \mathrm{~km} / \mathrm{h}$ (on average), and up to $200 \mathrm{~km} / \mathrm{h}$ along 90 percent of the length of the line. The entire Polish section is estimated to cost $€ 820 \mathrm{~m}$, with GDDKiA again serving as the investor, and the extension to Helsinki is estimated to cost ca. $€ 6 \mathrm{bn}$. The highway project will begin with a Berlin-Warsaw connection, then turn north along the existing S8 and S61 roads through Ostrów Mazowiecka, Łomża, Ełk, and Suwałki before reaching the Lithuanian border at Budzisko; it will then continue to Kaunas, Rìga, Tallinn, and Helsinki. ${ }^{13}$

Currently under construction and scheduled for completion by 2022, the A1 route-known in Poland as the Amber Highway-runs from Gorzyczki at the Czech border to Gdańsk via Katowice, Częstochowa, Łódź, and Toruń, and is another example of improvements to the road transport network. The name of the road is a symbolic reference to the ancient Roman trade route from Aquileia through the Moravian Gate (the pass between the Sudeten and the Carpathian mountains), north, to the oldest Polish city of Kalisz (known to Romans as Calisia), then to the Baltic Sea. The modern Amber Highway already exists in Poland and needs only to be extended to the south. It will form a part of the European transport corridor E75 that runs from Vardø in

\footnotetext{
12 The width of train rails in Russia, which was inherited by train rails in the Baltic States and western Ukraine as a result of the Soviet occupation, is greater than the width of train rails in Europe, which measure 1,520 mm (59.8 in). The train rails in Galicia, Transcarpathian Ukraine, and northern Bukovina, as part of the Habsburg Monarchy before 1918, had the width of European rails, while the train rails in western Volhynia-first, part of the Russian Empire (1795-1918) and then, part of interwar Poland (1919-39) - had been converted to European width. The width of train rails in all those territories was adjusted to the width of train rails in the Soviet railway system when these countries were conquered by the Soviet Union in the years 1939-45.

13 The interest of Finland in the project was acknowledged by the Finnish minister of transport and communication, Anne Berner, in December 2018. Finland is additionally interested in the Rail Baltica project due to the proposed construction of the railway tube in the Finnish Bay seabed, from Tallinn to Helsinki (ca. $80 \mathrm{~km}$ ), with probable completion by 2024 (Wójtowicz).
} 
northern Norway through Finland and onward via the Helsinki-Gdynia ferry connection to Poland before proceeding through Czechia, Slovakia, Hungary, Serbia, and Macedonia to Greece. It intersects the E30 (Cork, Ireland, to Omsk, Russia) and the E40 (Calais, France, to Ridder, Kazakhstan), making it an important element of the overall European transportation infrastructure.

The S3 expressway (from Świnoujście at the Baltic coast near the German border, south to Lubawka at the Czech border) has been completed and will be supplemented with an onward connection to Czechia by 2023. The S3 constitutes a part of the European E65 transportation corridor and Route 65 of the central European transport corridor (CETC), and runs from Sweden (via the Malmö-Świnoujście ferry connection) to Poland, Czechia, Slovakia, Hungary, Croatia, Kosovo, Serbia, Macedonia, and Greece, with a ferry connection to Crete.

Also worth mentioning is the so-called GO Highway linking Odesa to Gdańsk and connecting Ukraine and Poland. It will start in Gdańsk, go to the Ukrainian border near Lviv, and run further through TernopilKhmelnytskyi-Vinnytsia up to Uman, where it meets with the Kyiv-Odesa highway. Efforts to gain EU financial support for the GO highway seem to have been successful ("UE ma wesprzeć finansowanie").

Both road and rail infrastructure will be developed due to the Trimarium Initiative. The priority is the Rail Baltica (Warsaw-Tallinn) project, expected to be completed by 2025, with an undersea tunnel to Helsinki by the mid-2030s (Planowana infrastruktura Trójmorza 19-26).

Three water routes will be built in the Trimarium transportation network: the E30 (from Świnoujście on the Baltic Sea along the Oder, the Elbe, and the Danube rivers to the Black Sea), the E40 (connecting Baltic and Black seas from Gdańsk to Odesa), and the E70 (connecting the Oder and Vistula rivers to ultimately link Klaipèda and Rotterdam) (Planowana infrastruktura Trójmorza 31-35; Sienkiewicz 149-50). 
Figure 2. Trimarium existing and planned transport infrastructure. ${ }^{14}$

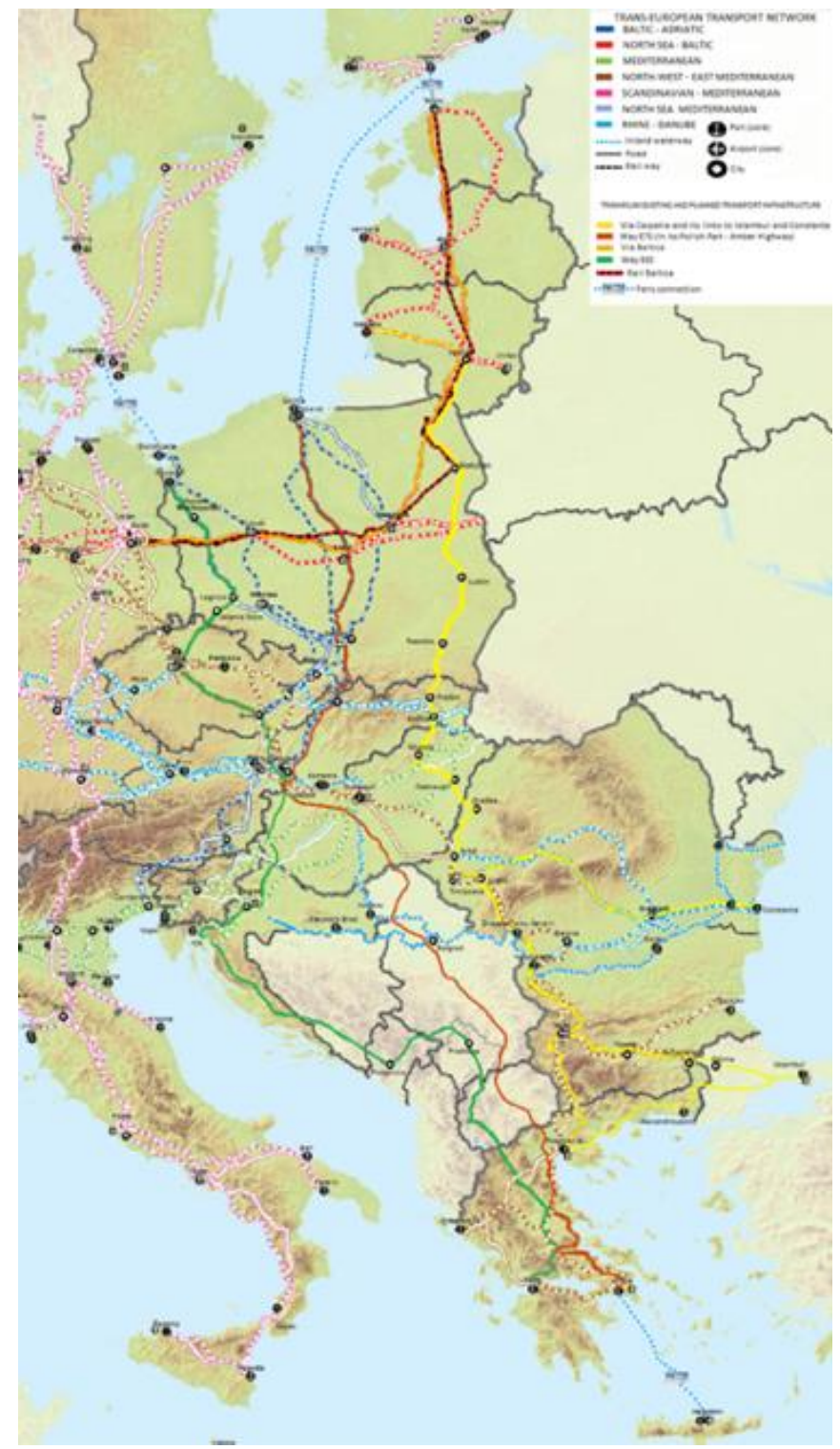

14 “Trans European Transport Network (Ten-T Corridors)," Reddit, https://www.reddit.com/r/europe/comments/3aq81n/transeuropean transport network tent_corridors/. Accessed 7 June 2021.

(C) 2021 East/West: Journal of Ukrainian Studies (ewjus.com) ISSN 2292-7956

Volume VIII, No. 2 (2021) 


\section{Goal Number 2: Transit Infrastructure of Energy and Raw Materials}

The energy dimension of TI co-operation was born as a tool to meet the Russian challenge to the region engendered by the Russian-Ukrainian "gas wars"15 that began just after the first Maidan demonstration in 2004, reached a climax in 2009, and have been accompanied by Russian military aggression against Ukraine since 2014 (Planowana infrastruktura Trójmorza 3). The Trimarium answer to that challenge is embodied in the North-South Corridor (NSC) project, that will connect the already existing liquid natural gas (LNG) terminal in Świnoujście on the Baltic coast, not far from the PolishGerman border, and the planned facility on the Croatian island of Krk on the Adriatic Sea. The NSC project began with the launch of Polish-DanishNorwegian Northern Gateway project-the building of a Baltic pipeline to bring gas from Norwegian gas fields to Poland. The investors are Gaz-System (Poland), Gassco (Norway), and Energinet (Denmark). The main gas distributor in Poland, PGNiG, is also engaged in the project, as its subsidiary PGNiG Upstream Norway holds shares in 20 Norwegian gas fields in the North Sea. The project, which has an estimated cost of €1.6-2.2 bn and a planned capacity of 10 billion cubic meters (bcm) per year, is scheduled to be completed in 2022, and will be able to operate in reverse mode as well as in direct mode ("Gazociąg Baltic"; "PGNiG on the Norwegian"). For these investments to be effective, they must be coupled with a body of interconnectors between the V4 countries and their Trimarium neighbours, as well as Ukraine. In particular, the creation of the north-south gas transit corridor demands the construction of three further interconnectors: PolishUkrainian interconnector between Hermanowice (Poland) and Drozdovychi (Ukraine), completed in 2020 (Sprawozdanie z działalności 224); PolishSlovak interconnector, to be completed by 2022 (Sprawozdanie $Z$ działalności 221); and Polish-Czech interconnector, for which a deadline has yet to be established.

The Polish-Slovak interconnector (facility connecting one country's gas pipeline system with the system of another country) is planned to be built between Strachocin and Vel'ké Kapušany. Its annual capacity will be 4.7 bcm (Poland to Slovakia) and $5.7 \mathrm{bcm}$ (Slovakia to Poland). The main investors are Gaz-System (Poland) and Eustream (Slovakia), and the estimated cost is

\footnotetext{
15 Other countries have faced Russian "gas blackmail" since the beginning of the 1990s. See Żurawski vel Grajewski, Polityka Unii Europejskiej 504-18, 521-51; Wyciszkiewicz 34-36, 54-55; Adam Eberhardt; Szeptycki, "Stosunki" 103-04, 119-20. The Ukrainian-Russian gas conflicts (2005-14) have raised the question to its present level of urgency. See Szeptycki, "Stosunki" 123-30; Szeptycki, Ukraina 186-89; Żurawski vel Grajewski, "Unia Europejska."
} 
$€ 83 \mathrm{~m}$. The project has been supported with €108 $\mathrm{m}$ in EU funding provided within the framework of the Connecting Europe Facility instrument.

The Polish-Czech interconnector will stretch from Libhošt' (Czechia) to Hat' (at the Polish-Czech border) and will continue to Kędzierzyn Koźle (Poland). Its capacity is planned to be $5 \mathrm{bcm}$ (Poland to Czechia) and $2.5 \mathrm{bcm}$ in the reverse direction; costs have not yet been estimated, although the main investors will be Gaz-System (Poland) and Netgas (Czechia).

The Polish-Ukrainian interconnector is planned to stretch from Hermanowice (Poland) to Bilche-Volytsia (Ukraine), with a compressor station in Strachocin (Poland). Its planned capacity is $5-8 \mathrm{bcm}$ per year. The interconnector's main investors are Gaz-System and Ukrtranshaz.

For Poland and Ukraine, interconnections of gas pipeline are rooted in energy security concerns; the Russo-Ukrainian war has forced Ukraine to seek gas suppliers in addition to Russia's Gazprom. The Polish budget does not depend on revenues from Russian gas transit fees, since the amount of money earned in that way by Poland is negligible. Unfortunately, that is not the case for Ukraine; the Ukrainian budget would suffer much more without this income. For Czechia and Slovakia, the respective interconnectors have a much greater economic dimension; nonetheless, the Russian-German Nord Stream 2 represents a fundamental threat to Slovak and Ukrainian positions as the main transit countries for Russian gas, thereby forcing Bratislava and Kyiv to search for alternatives. In 2014 The Slovakian reverse capacity $(9.85$ bcm per year in 2009, upgraded by 2015 to $14.3 \mathrm{bcm}$ ) was the only capacity large enough to possesses a strategic scale in the region (the Polish and the Hungarian reverse capacities due to technical limits were too small), and it was thanks to Slovak assistance that Ukraine survived the first post-Maidan winter (2014-15), cut off from Russian gas supplies (Kardaś et al.). In March 2018 Poland supported Ukraine very effectively with urgent gas reverse supplies when Gazprom again cut off Ukrainian supplies ("Pol's'ka PGNiG"). Russia's gas blockade of Ukraine in 2009 showed that any country could have its Russian gas supply cut off-including the Russian protectorate in Transnistria as well as Czechia or Bulgaria (both of whom are relatively friendly to Russia), or even Germany, which is Russia's main partner on the Nord Stream 2 project and Russia's main gas customer. This is why nations afraid of Russian "gas blackmail" have decided to base their energy security on more tangible guarantees than gas contracts with Moscow. The solution is liquified natural gas (LNG) that can be transported along the maritime routes from various countries all over the world-first and foremost, from the U.S.

New U.S. gas export policies have boosted American interest in the European gas market. Polish citizens have no doubt that they would prefer to buy gas from the U.S. rather than from an aggressive Russia. On 16 June 2017, an American gas (LNG) shipment reached Świnoujście, followed by 
President Trump's announcement in Warsaw in July that the U.S. will supply Central Europe with American LNG ("Pierwszy statek"; DiChristopher). On 21 November 2017, a mid-term Polish-American contract for the provision of U.S. LNG to Poland was signed ("Przełomowy kontrakt"). In October 2018, the U.S. contracted Venture Global Calcasieu Pass, LLC and Venture Global Plaquemines LNG, LLC to send LNG to Poland-this time for twenty-four years. The agreement is unprecedented in Europe, with the right to re-export the gas (which is not the case with contracts with Russia), and with prices twenty percent lower than those offered by Gazprom ("Gaz z USA przypłynie"; "Sukces polityki energetycznej Polski”; Frączyk). Trimarium cooperation in the energy dimension was considerably encouraged by these contracts between Poland and America.

There is both hope and challenge in this situation, since the mouth of the planned Russian-German Nord Stream 2 is situated in Greifswald, just a dozen kilometres west of Świnoujście. Due to this fact, the Russian-German initiative may again result in saturation of the central European gas market with Russian gas, thus rendering it vulnerable to political pressure from Moscow. That is why it is crucial for the European Commission to impose the acquis communautaire on all parts of Nord Stream 2, including the stretch on the Baltic seabed, and on the Opal Gas pipeline-i.e., to extend the third European legislative package on energy to this project. This should result in an effective unbundling of energy production and supply interests from the network. Unfortunately, decisions taken in mid-February of 2019 by the German-dominated EU make such a scenario less probable (Stearns; Vaughan). The U.S. political pressure on German, French, and Dutch companies engaged in the project is crucial under these circumstances.

U.S. interest in the central European LNG market and U.S. Congress acts targeted against Nord Stream 2 give some basis for optimism and are welcomed by Poland as effective American support for the TI. The American actions dovetail perfectly with the Trimarium LNG infrastructure projects.

As the north-south gas transit corridor is to be combined with LNG terminals at both ends - in Świnoujście and Krk, respectively-in Poland the project is treated as a re-insurance to guarantee the security of gas supply to the region in the event of Russian interruptions of LNG shipments to Świnoujście via the Baltic Sea (Planowana infrastruktura Trójmorza 6-11). Apart from the north-south corridor, gas interconnection Poland-Lithuania (GIPL) between Hołowczyce (Poland) and Jauniūnai (Lithuania) is planned to be completed by July 2022 ("Gazociąg Polska-Litwa"). The investors are Gaz-System, Amber Grid (Lithuania), and the Innovation and Network Executive Agency (INEA) in the EU. With an estimated cost of $€ 558 \mathrm{~m}, \mathrm{GIPL}$ is intended to connect the Baltic states' gas grid with the grid that supplies the entire EU; however, complications might arise due to the competitive nature of LNG terminals that include existing facilities in Polish Świnoujście 
and the floating storage regasification unit (FSRU) in Klaipeda, as well as the additional FSRUs planned to be built in Skulte (Latvia), Tallinn and Paldiski (Estonia), and Constanţa (Romania) (Planowana infrastruktura Trójmorza 12-14; Stoica).

The struggle against the German-Russian Nord Stream 2 project $^{16}$ engages Poland and Slovakia within the TI, and Ukraine and Belarus outside the TI (Maciążek). All of these states are currently the main transit countries for Russian gas and oil exports to the EU (Konończuk). ${ }^{17}$ It is highly probable that these states will co-operate with the Scandinavian and the Baltic countries on this issue, since all of them fear Russian domination in the region and perceive Russian gas exports to be an instrument of the Kremlin's foreign policy.

The energy infrastructure of the TI might be supplemented by two electricity interconnections, the LitPol Link between Ełk in Poland and the Alytus in Lithuania, thereby connecting Poland and the Baltic states; this link between Poland and Ukraine is currently in the planning phase (Planowana infrastruktura Trójmorza 27-30).

\section{Goal Number 3: Digitization}

Member states' co-operation within the scope of digitization is the third dimension of the TI. Digitization is declared to be basic, as the countries in the TI region (except for Austria, which is a part of the "old West") need to cease building a competitive advantage on the basis of cheap labour and start to support innovation and high-tech development. Unfortunately, the region has experienced a tremendous "brain drain" since its accession to the EU, which will have a long-term negative impact on high-tech development. Future generations of young, competent IT specialists must be able to find jobs in their own countries in IT sectors that are competitive with western standards. The high-tech sector appears to be the most logical engine for such a plan. Future economic growth will likely come from areas of artificial intelligence and automation that are currently not sufficiently researched in TI member states. Investments in information and communications technology (ICT) are therefore indispensable, and the lack of capital in the region makes the coordination of resources essential. The countries in the Three Seas region need to identify complementary areas in which to

\footnotetext{
16 While Nord Stream 2 encompasses more than just German and Russian companies, it is essentially a Russian-German project (Łoskot-Strachota et al.; see also Sadecki et al.; Groszkowski; Gotkowska and Szymański).

17 For more, see Żurawski vel Grajewski, "Unia Europejska” 203; and Kłysiński and Konończuk.
} 
specialize (Baeva-Motusic 26-27). For example, cybersecurity is crucial, considering the Russian cyber-warfare directed against those countries in 2007, during the Estonian-Russian "bronze soldier war" (Terlikowski; "Russia's Involvement"; Torsti 19-35). Additionally, frequent floods in Poland and in the Carpathian basin and industrial pollution of the waters, inherited from the communist times, are challenges that could be monitored with digital technology. The TI summit in Slovenia (5-6 June 2019) resulted in the adoption of two such projects:

(1) The digital platform for monitoring hydrographic bases in the TI region was initiated by Romania and has received the co-operation of all twelve TI member states, plus partner countries (Albania, Moldova, Serbia, Turkey, Ukraine). The platform will monitor water from hydrographic basins in the Trimarium region. It will model pollutants, measure water discharge, analyze risk, monitor water currents, and calculate water quality parameters. The project recognizes the policies and priorities of the EU, particularly the Water Framework Directive and the Marine Strategy Framework Directive. The goal of the planned platform is to analyze flood risks, predict droughts and water shortages, and estimate the impact of water abstraction in the region surrounding TI members and affiliates, taking into account the effects of changes in climate. The project is in its initial stage with an estimated budget of $€ 2.5$ billion. The project documentation was prepared, the business plan was conceived, and the rate of profitability was calculated in 2019 .

(2) U-space, low altitude space as a new field of economy. Central European Drone Demonstrator (CEDD)-is a project initiated by Poland in which all TI countries, as well as Ukraine and Moldova, are invited to participate. Its main objective is to set up an environment that will enable the safe integration of drones into the airspace, and into the economy. The CEDD plans to create rules for the operation of the unmanned aerial vehicle (UAV) market and to implement aviation and IT/Telco infrastructure that will ensure safe and effective use of low-altitude space (U-space). The CEDD initiators of this plan are aviation market institutions: the Civil Aviation Office (ULC) is the regulator, the Polish Air Navigation Services Agency (PANSA) is the airspace manager, and the metropolitan union is GZM Metropolis.The project began on 31 March 2019 and is expected to be completed by the end of 2021 .

(3) The 3 Seas Digital Highway was initiated by Poland in 2018. It is open to all twelve TI member states, and there is great hope that the 
Scandinavian countries will join. The project was inspired by the Baltic Highway (a fibre-optic network connecting Tallinn and Frankfurt via Riga, Vilnius, Warsaw, and Berlin, launched in 2015) that, like many other similar investment projects, aims to connect western and eastern Europe. The aim of the Polish project is to connect the north and the south of the TI area in a similar way. The construction of the 3 Seas Digital Highway can encourage the development of modern 5G wireless technology and improve the ecosystem common to the Three Seas countries that are involved in it. The project was expected to be completed by the end of 2020 , but the COVID-19 impact on budgets must have caused some delay.

(4) Three Seas Initiative (3SI) Marketplace-another Polish project of 2018 - aims to enhance mutual trade and investments, and to build regional value chains by creating a digital imports-exports platform to help TI manufacturers find the right business partner, the appropriate merchandise, and viable markets. The 3SI is expected to set up a platform providing information on enterprise acquisition within the TI countries to ensure the uninterrupted activities of family businesses faced with succession problems by facilitating a friendly takeover; hasten the scaling up process of small and medium enterprises (SMEs) in need of investments; enhance capital flows and the regional enterprise integration necessary for foreign expansion to external markets; and enable a transparent privatization process where needed. The platform was expected to be launched by the end of 2020, but this has not been realized yet.

(5) Interoperability solutions for a digitized and sustainable energy sector in the 3 Seas Initiative area in the field of energy storage-initiated by Romania in 2019. The goal here is to define and create an intelligent digital platform in the field of energy storage (electricity and natural gas) in the TI region. Its planned budget is $€ 10$ million. The project is expected to be completed by January 2022.

(6) Transportation stock exchange in the 3 Seas region-proposed by Romania in 2019. The plan is to create an intelligent digital platform for transport and logistic services in the TI region. The project covers the twelve TI member states as well as Albania, Moldova, Serbia, Turkey, and Ukraine.

Finally, following in the steps of Mike Pompeo's announcement (on 15 February 2020) of $\$ 1$ billion in American governmental support for the TI, 
Microsoft and Google followed with $\$ 1$ billion and 2 billion investments, respectively, in Poland's data centre in 2020 (Jones et al.; "Microsoft Announces"; "Google to Invest"). These investments provide an excellent basis for substantial growth in digital know-how and capacity in the TI region.

\section{UKRAINE AS A PARTNER IN THE TRIMARIUM INITIATIVE}

At a joint press conference with Polish President Andrzej Duda on 31 August 2019, in Warsaw, Ukrainian President Volodymyr Zelens'kyi expressed Ukraine's will to join the TI ("Zelensky"). Since then, this has been the official position of Ukraine ("President: Ukraine Is Interested"). Such a declaration is more a symbol than a political plan. The reality is that Ukraine is not an EU member state, and many of the "twelve" are not ready to open the TI to nonEU countries. However, Ukraine has been included in several of the projects mentioned above. It is a full participant in the principal project of the TIthe highway Via Carpatia-and is active in another project to diversify gas supply sources and integrate infrastructure in the Three Seas Region, together with Poland, Slovakia, Denmark, and Norway. The latter project aims to establish a large transportation corridor between Poland and Ukraine and includes the construction of a new gas pipeline through the Polish-Ukrainian border, a modernization of the compressor station in Strachocina, and an extension of the internal transmission systems in both Poland and Ukraine. The diversification of gas supply sources will achieve a Polish-Ukrainian gas interconnection with a capacity of $5 \mathrm{bcm}$ per year. The project is expected to be completed in 2022 (Priority Interconnection Projects 29-41).

Apart from these two most important projects, Ukraine participates in (1) the transportation stock exchange in the 3SI region; (2) the digital platform for monitoring hydrographic bases in the TI region; (3) the Viking Train; ${ }^{18}$ (4) the Central European Drone Demonstrator (CEDD), described above; (5) construction of the second railway track between Koper and Divača; and (6) reconstruction of the Ljubljana railway junction (LRJ). Projects 5 and 6, although remote from Ukraine, constitute two parts of the

18 The Viking Train is a joint project of Lithuanian, Ukrainian, and Belarusian Railways, stevedore companies, and ports of Klaipeda, Chernomorsk, and Odesa. The route crosses Ukraine, Belarus, and Lithuania and links the network of maritime container lines and land container lines of the Baltic Sea and the Black Sea, and the Mediterranean and Caspian seas. The project is older than the TI-the regular runs were launched on 6 February 2003; still, the TI mention it as one of its initiatives in Priority Interconnection Projects 2019 Status Report. 
railway network that connects Ukraine with western Europe. Additionally, Ukraine is considered a future partner in the TI project involving the Romanian-Hungarian-Slovak gas transmission corridor that will be used for gas transit to Ukraine (Priority Interconnection Projects 50, 54, 57, 88-89, $183,185,203)$. The TI summit in Tallin (19-20 October 2020) was expected to strengthen the ties between the TI and Ukraine, but, although fruitful, the summit did not bring any substantial decisions about the co-operation with Ukraine (Żurawski vel Grajewski, "V Szczyt Trójmorza”).

\section{CONCLUSION}

The Trimarium Initiative is a platform for infrastructural (transport and communication, raw energy materials transit, digitization) co-operation and has no potential to be turned into a homogenous political bloc. It remains what it is expected to be-a forum of twelve countries that found common ground and common interests. Unlike its interwar predecessors, it enjoys the support of the world's superpower-the United States, acknowledged by the U.S. Congress in November 2020 with a bipartisan resolution, and that gives hope that the initiative will succeed (Żurawski vel Grajewski, "Trójmorze w grze"). The TI differs from another historical project that attempted an economic integration of the region. It was imposed on the Soviet controlled states by the USRR-the Council for Mutual Economic Assistance (Comecon) (1949-91). All the countries that co-operate in the TI are politically independent and have decided to join voluntarily. No state is a satellite state of any other state, and there is no hegemony in the construction.

The TI is still under construction, yet it is developing rapidly and attracting more and more interest. There are numerous technical issues to be settled. A strategic question yet to be decided is how much each member state will commit to the TI fund. Given the multinational nature of the TI, another key task is to establish and co-ordinate points of contact for investors in search of information about TI projects. Investors also need to know whether some of the big cross-border plans envisaged by the TI will be run via complex multinational tenders or broken down into simpler national chunks, and how public-private partnerships will be structured. Grand projects such as the Via Carpatia need to be broken down into manageable pieces that individual investors can participate in (Shotter).

Technical questions remain a challenge; still, the general political character of the TI is clear. It is not intended to replace the EU or NATO and it has not been created "against" anybody; it was established to promote regional co-operation. It is primarily about infrastructure, and thus its economic dimension is fundamental to the initiative. Nevertheless, the 
economic goals, once achieved, will have political consequences. If we recall, that was the original logic of the European integration process, and that logic might be repeated on a regional scale in the Trimarium area. With its present focus on infrastructure, the TI might strengthen transatlantic relations, in part by attracting U.S. engagement via LNG supplies to the region. The TI can also provide infrastructure links in transport and energy between TI members and Ukraine. Only one year after the official launch of the Trimarium Initiative, Ukraine became, with Polish support, a part of the TI's main project, Via Carpatia.

In order to survive, the Trimarium should not follow the model of domination employed by the EU's core countries. The TI must be based on the old Jagiellonian principle "Equal with equals, free with free," where nobody wields hegemony. Poland is still the largest (by population) country of the Trimarium. The success of the Trimarium Initiative depends on the genuine support of the smaller member states, and this may be won only by real, not merely rhetorical, respect for their dignity and interests. Poland persuaded the TI members to co-operate with Ukraine in a very nuanced way. Should this effort be properly understood in Kyiv, the common goals of Ukraine and Poland will be smoothly achieved. 
Figure 3. Trimarium infrastructural projects as of 2017.19

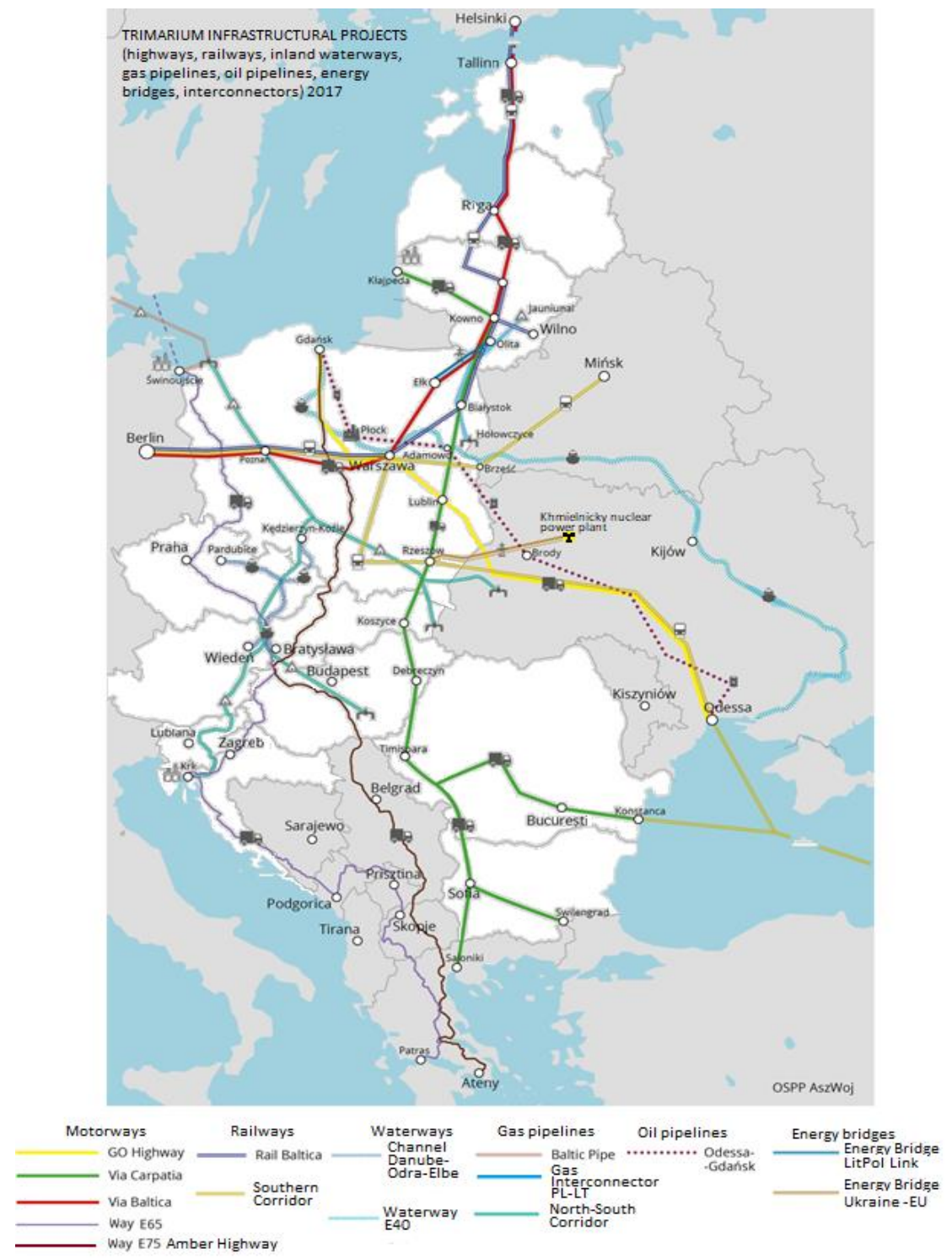

19 P. Zhuravs'kyi-vel'-Hraievs'kyi (P. Żurawski vel Grajewski), "Trymor"ia-pohliad z pivnochi," Chornomors'ka bezpeka, vol. 2 (30), 2017, 51, https://geostrategy.org.ua/chornomorska-bezpeka/831/832. Accessed 22 June 2021. 


\section{Works Cited}

Baeva Motusic, Andreana. "The Three Seas Initiative: A Vision for a Way Forward for South Eastern EU Member States." Adriatic-Baltic-Black Sea Visions of Cooperation, edited by Kinga Redłowska, Institute for Eastern Studies, 2017, pp. 21-28.

Bieliszczuk, Bartosz, and Marek Wąsiński. "Transformacja energetyczna na obszarze Trójmorza w latach 1988-2018." Polski Przegląd Dyplomatyczny, vol. 2, no. 77, 2019, pp. 87-98.

"Boosting NATO's Presence in the East and Southeast." North Atlantic Treaty Organization, 29 June 2017, http://www.nato.int/cps/en/natohq/topics_136388.htm?selectedLocale=en. Accessed 7 June 2021.

Brzeziński, Ian, and David Koranyi. "The Three Seas Summit: A Step toward Realizing the Vision of a Europe Whole, Free, and at Peace?" Atlantic Council, 5 July 2017, http://www.atlanticcouncil.org/blogs/new-atlanticist/the-three-seas-summita-step-toward-realizing-the-vision-of-a-europe-whole-free-and-at-peace. Accessed 7 June 2021.

Charrel, Marie. "La 'petite Chine d'Europe" voit l'avenir en grand." Le Mond, 4 June 2020, https://www.lemonde.fr/economie/article/2020/06/04/la-petitechine-d-europe-voit-l-avenir-en-grand_6041684_3234.html. Accessed 7 June 2021.

Cieplucha, Piotr. "Prometeizm i koncepcja Międzymorza w praktyce politycznoprawnej oraz dyplomacji II RP.” Studia Prawno-Ekonomiczne, vol. XCIII, 2014, pp. 39-55.

Czernicka, Marzena. “Trójmorze w bułgarskiej polityce bezpieczeństwa." Przegląd Geopolityczny, no. 26, 2018, pp. 142-54.

Dahl, Martin. "Inicjatywa Trójmorza z perspektywy niemieckiej." Studia Europejskie, no. 2, 2018, pp. 59-72.

Dębiec, Krzysztof, and Jakub Groszkowski. "The Presidential Election in Slovakia: A Vote for Change." OSW Analyses, 18 Mar. 2019, https://www.osw.waw.pl/en/publikacje/analyses/2019-03-18/presidentialelection-slovakia-a-vote-change. Accessed 7 June 2021.

DiChristopher, Tom. "Trump Pitches US Natural Gas to European Leaders, Suggests Russian Gas Holds Them Hostage." CNBC, 6 July 2017, http://www.cnbc.com/2017/07/06/trump-natural-gas-europe-leaders.html. Accessed 7 June 2021.

Dobija, Mieczysław. "[Response to] Ankieta Arkanów: Ekonomiczne i kulturowe podstawy Trójmorza." Arcana. Kultura, Historia, Polityka, vol. 5, no. 137, 2017, pp. 25-28.

“Druga para pociągów Kijów-Przemyśl ruszy 24 sierpnia." Rynek Kolejowy/inf. Prasowa, 28 July 2017, http://www.rynek-kolejowy.pl/wiadomosci/bedziedruga-para-pociagow-kijow--przemysl-82822.html. Accessed 7 June 2021.

Eberhardt, Adam. "Problematyka energetyczna w stosunkach Federacji Rosyjskiej i Republiki Białoruś." Geopolityka rurociagów: Współzależność energetyczna a stosunki międzypaństwowe na obszarze postsowieckim, edited by Ernest Wyciszkiewcz, PISM, 2008, pp. 67-72. 
Eberhardt, Piotr. "[Response to] Ankieta Arkanów: Ekonomiczne i kulturowe podstawy Trójmorza." Arcana. Kultura, Historia, Polityka, vol. 5, no. 137, 2017, pp. 20-21.

Eddy, Melissa. "The Bride Was a Dream in a Dirndl, but Putin Stole the Show." The New York Times, 18 Aug. https://www.nytimes.com/2018/08/18/world/europe/putin-austriawedding-foreign-minister.html. Accessed 7 June 2021.

European Economic Forecast: Spring 2020. Institutional Paper, no. 125, May 2020, https://ec.europa.eu/info/publications/european-economic-forecast-spring2020 en. Accessed 21 June 2021.

Foreign Trade. Ranking of Germany's Trading Partners in Foreign Trade 2016. Statistisches Bundesamt, 20 July 2017.

Frączyk, Jacek. “Gigantyczna umowa PGNiG. Gaz z USA zastąpi rosyjski.” Money.pl, 27 June 2018, https://www.money.pl/gospodarka/wiadomosci/artykul/pgniggaz-lng-usa-port-arthur-venture-global,11,0,2409739.html. Accessed 7 June 2021.

“Gaz z USA przypłynie do Świnoujścia. Kontrakt na 24 lata.” TVN Fakty, 8 Nov. 2018, https://fakty.tvn24.pl/ogladaj-online,60/polska-podpisala-umowe-nadostawy-gazu-z-usa-na-24-lata,882147.html. Accessed 7 June 2021.

"Gazociąg Baltic Pipe coraz bliżej. Naimski: Jest oczywistą rzeczą, że zdążymy." Dziennik.pl, $30 \quad$ Mar. 2017, http://gospodarka.dziennik.pl/news/artykuly/546252,baltic-pipe-gazociagrura-naimsk-projekt.html. Accessed 7 June 2021.

"Gazociąg Polska-Litwa." GAZ-SYSTEM S.A., https://www.gaz-system.pl/naszeinwestycje/integracja-z-europejski-systemem/polska-litwa/. Accessed 21 June 2021.

“GDP Growth (Annual \%)-European Union.” The World Bank, https://data.worldbank.org/indicator/NY.GDP.MKTP.KD.ZG?locations=EU. Accessed 7 June 2021.

Gizicki, Wojciech. "Geopolityka Trójmorza." Przestrzeń Społeczna/Social Space, 8 April 2019, pp. 1-15.

Global Forum 2017. Warsaw Institute, 7 July 2017, https://warsawinstitute.org/pl/global-forum-2017/. Accessed 7 June 2021.

Gnauck, Gerhard. "Wie sich Polen gegen die Krise stemmt." Frankfurter Allgemeine Zeitung, 30 April 2020.

Gniazdowski, Mateusz. "[Response] Trójmorze-nowy instrument w Polskiej polityce zagranicznej." Polski Przegląd Dyplomatyczny, vol. 4, no. 71, 2017, pp. 79-82.

Gojke, Wojciech. "Nowe połączenie kolejowe z Przemyśla do Lwowa i Kijowa." WP Turystyka, 22 Dec. 2016, https://turystyka.wp.pl/nowe-polaczenie-kolejowe-zprzemysla-do-lwowa-i-kijowa-6071929991451777a. Accessed 7 June 2021.

“Google to Invest Up to \$2 Billion in Polish Data Centre, Paper Says." Reuters, 24 June 2020, https://www.reuters.com/article/us-google-poland/google-to-investup-to-2-billion-in-polish-data-centre-paper-says-idUSKBN23V0PA. Accessed 7 June 2021. 
Gotkowska, Justyna, and Piotr Szymański. "Nordycy wobec Nord Stream 2-między sceptycyzmem a neutralnością." Komentarze OSW, 12 Oct. 2016, pp. 1-7, https://www.osw.waw.pl/sites/default/files/komentarze_223_0.pdf. Accessed 21 June 2021.

Grosse, Tomasz Grzegorz. “O polityczności dwupoziomowego systemu politycznego w Europie." Multilevel Governance w Unii Europejskiej, edited by J. Ruszkowski and L. Wojnicz, 2013, pp. 133-51.

Groszkowski, Jakub. “Czesi wobec Nord Stream 2." Analizy OSW, 9 Dec. 2015, https://www.osw.waw.pl/pl/publikacje/analizy/2015-12-09/czesi-wobecnord-stream-2. Accessed 7 June 2021.

Héji, Dominik. "[Response] Trójmorze-nowy instrument w Polskiej polityce zagranicznej." Polski Przeglad Dyplomatyczny, vol. 4, no. 71, 2017, pp. 68-78.

"Infrastructure and Investment." European Commission: Mobility and Transport, https://ec.europa.eu/transport/themes/infrastructure en. Accessed 7 June 2021.

Ioniță, Ion M., and Octavian Manea. "Vershbow: NATO Needs Strategy to Address Threats from the South and the East." Defence Matters, 5 Nov. 2015, http://defencematters.org/news/vershbow-nato-needs-strategy-to-addressthreats-from-the-south-and-the-east/410/. Accessed 7 June 2021.

Janduła, Martyn. "Ruszyło połączenie Chełm-Kowel. Zapowiedź kolejnego połączenia do Kijowa." Rynek Kolejowy/inf. Prasowa, 12 June 2017, http://www.rynek-kolejowy.pl/wiadomosci/ruszylo-polaczenie-chelm-kowel-zapowiedz-kolejnego-polaczenia-do-kijowa-82148.html. Accessed 7 June 2021.

"Joint Declaration on 'Allied Solidarity and Shared Responsibility.' Bucharest, Nov. 2015." President of the Republic of Lithuania, 2015, https://www.lrp.lt/data/public/uploads/2015/11/joint-declaration.pdf. Accessed 7 June 2021.

"Joint Statement by Estonia, Latvia, Lithuania, Poland and Romania on the Occasion of 80 Years since the Signing of Molotov-Ribbentrop Pact." Gov.pl: Website of the Republic of Poland, 23 Aug. 2019, https://www.gov.pl/web/diplomacy/jointstatement-by-estonia-latvia-lithuania-poland-and-romania-on-the-occasion-of80-years-since-the-signing-of-molotov-ribbentrop-pact. Accessed 7 June 2021.

Jones, James L. Jr., et al. "US Commits \$1 Billion Dollars to Develop Central European Infrastructure." Atlantic Council, 15 Feb. 2020, https://www.atlanticcouncil.org/news/press-releases/us-commits-1-billiondollars-to-develop-central-european-infrastructure/. Accessed 7 June 2021.

Kardaś, Szymon, et al. "Negocjacje gazowe Ukraina-Rosja-UE: wojna pozycyjna." $\begin{array}{lllll}\text { Analizy } & \text { OSW, } & 8 & \text { Oct. } & 2014,\end{array}$ http://www.osw.waw.pl/pl/publikacje/analizy/2014-10-08/negocjacjegazowe-ukraina-rosja-ue-wojna-pozycyina. Accessed 7 June 2021.

Kłysiński, Kamil, and Wojciech Konończuk. "Rosja prowokuje konflikt gazowy z Białorusią." Analizy OSW, 23 June 2010, https://www.osw.waw.pl/pl/publikacje/analizy/2010-06-23/rosjaprowokuje-konflikt-gazowy-z-bialorusia. Accessed 7 June 2021. 
Konończuk, Wojciech. “Gazprom zapowiada spadek tranzytu gazu przez Ukrainę.” $\begin{array}{lllll}\text { Analizy } & \text { OSW, } & 1 & \text { June }\end{array}$ http://www.osw.waw.pl/pl/publikacje/analizy/2011-06-01/gazpromzapowiada-spadek-tranzytu-gazu-przez-ukraine. Accessed 7 June 2021.

Kowal, Paweł, and Agnieszka Orzelska-Stączek. Inicjatywa Trójmorza: geneza, cele i funkcjonowanie, 3 East of the West Wschód Zachodu. Instytut Studiów Politycznych PAN, 2019.

Krekó, Péter, and Patrik Szicherle. "Why Is Hungary Blocking Ukraine’s Western Integration?" Atlantic Council, 16 Jan. 2018, https://www.atlanticcouncil.org/blogs/ukrainealert/why-is-hungaryblocking-ukraine-s-western-integration/. Accessed 7 June 2021.

“Łańcut Declaration.” Prezydent.pl, 27 Oct. 2006, https://m.prezydent.pl/en/archive/news-archive/news-2006/art,130,lancutdeclaration.html. Accessed 7 June 2021.

"10 lat Deklaracji Łańcuckiej, czyli krótko o Via Carpatia." Muzeum Zamek w Łańcucie. https://www.zamek-lancut.pl/pl/Aktualnosci,357. Accessed 7 June 2021.

Łoskot-Strachota, Agata, et al. "Porozumienie w sprawie finansowania Nord Stream 2." Analizy OSW, $26 \quad$ April https://www.osw.waw.pl/pl/publikacje/analizy/2017-04-26/porozumieniew-sprawie-finansowania-nord-stream-2. Accessed 7 June 2021.

Maciążek, Piotr. "Polska przeciw Nord Stream II. Prawo UE musi być przestrzegane." Energetyka 24, 11 Sept. 2015, http://www.energetyka24.com/258026,polskaprzeciw-nord-stream-ii-prawo-ue-musi-byc-przestrzegane. Accessed 7 June 2021.

"Microsoft Announces a \$1 Billion Digital Transformation Plan for Poland, Including Access to Local Cloud Services with First Datacenter Region." Microsoft, 5 May 2020, $\quad$ https://news.microsoft.com/europe/2020/05/05/microsoftannounces-a-1-billion-digital-transformation-plan-for-poland-includingaccess-to-local-cloud-services-with-first-datacenter-region/. Accessed 7 June 2021.

Milewski, Oktawian. "Trójmorze-nowy instrument w Polskiej polityce zagranicznej." Polski Przegląd Dyplomatyczny, vol. 4, no. 71, 2017, pp. 55-67.

National Security Strategy of the Republic of Poland. National Security Bureau, 2020, https://www.bbn.gov.pl/ftp/dokumenty/National Security Strategy of the R epublic of Poland 2020.pdf. Accessed 21 June 2021.

"NATO’s Enhanced Forward Presence." North Atlantic Treaty Organization, Aug. 2018, https://www.nato.int/nato_static_fl2014/assets/pdf/pdf_2018_09/20180910_ 1809-factsheet efp en.pdf. Accessed 7 June 2021.

"Nine Leaders of Central and Eastern European States Adopt Bucharest Summit Declaration: Commitment to Strengthen Eastern Flank of NATO and for Defence Budget." Nine O'Clock, 4 Nov. 2015, http://www.nineoclock.ro/nine-leaders-ofcentral-and-eastern-european-states-adopt-bucharest-summit-declarationcommitment-to-strengthen-eastern-flank-of-nato-and-for-defence-budget/. Accessed 7 June 2021.

Okulewicz, Piotr. Koncepcja "Międzymorza" w myśli i praktyce politycznej obozu Józefa Piłsudskiego w latach 1918-1926. Wydawnictwo Poznańskie, 2001. 
Orzelska-Stączek, Agnieszka. "Inicjatywa Trójmorza w świetle teorii realizmu. Polityczne aspekty nowej formy współpracy dwunastu państw / The Three Seas Initiative in the Light of the Theory of Realism: The Political Aspects of the New Form of Cooperation between the Twelve Countries." Sprawy MIędzynarodowe, no. 1, 2019, pp. 131-55.

"PGNiG on the Norwegian Continental Shelf." PGNiG: Upstream Norway, http://norway.pgnig.pl/pgnig-on-the-ncs. Accessed 7 June 2021.

"Pierwszy statek z amerykańskim gazem w Świnoujściu. Szydło: To dzień, który przejdzie do historii." Dziennik.pl, 8 June 2017, http://gospodarka.dziennik.pl/news/artykuly/551707,gazowiec-lng-gazswinoujscie-statek-z-amerykanskim-gazem-dostawa-gazu-z-usa.html. Accessed 7 June 2021.

Planowana infrastruktura Trójmorza, Projekty szlaków transportowych PółnocPołudnie, (wg stanu na 7 czerwca 2017 roku). Informacja Ośrodka Studiów Przestrzeni Postsowieckiej, Centrum Badań nad Bezpieczeństwem Akademii Sztuki Wojennej, 2017.

"Poland GDP-Gross Domestic Product 2018." countryeconomy.com, https://countryeconomy.com/gdp/poland. Accessed 7 June 2021.

"Poland: Trump Visit Adds Heft to Three Seas Summit." Stratfor Worldview, 14 June 2017, https://worldview.stratfor.com/article/poland-trump-visit-adds-heftthree-seas-summit. Accessed 7 June 2021.

"Pol's'ka PGNiG pochala terminovi postavky hazu v Ukrainu." Ekonomichna Pravda, 2 Mar. 2018, https://www.epravda.com.ua/news/2018/03/2/634643/. Accessed 7 June 2021.

Poręba, Tomasz. "Via Carpathia-An Investment in the Future." The Warsaw Institute Review, 13 March 2018, https://warsawinstitute.org/via-carpathia-investmentfuture/. Accessed 7 June 2021.

"Powołamy forum biznesowe państw Trójmorza." Prezydent.pl, 6 July 2017, https://www.prezydent.pl/aktualnosci/wypowiedzi-prezydentarp/wystapienia/art,250,powolamy-forum-biznesowe-panstw-trojmorza.html. Accessed 7 June 2021.

"President Duda: Many Infrastructure Projects Possible in CEE." The Official Website of the President of the Republic of Poland, 6 July 2017, https://www.president.pl/en/news/art,493,president-duda-manyinfrastructure-projects-possible-in-cee-.html. Accessed 7 June 2021.

"President: Ukraine Is Interested in Joining the Three Seas Initiative." The Presidential Office of Ukraine Website, 26 Nov. 2019, https://www.president.gov.ua/en/news/ukrayina-zacikavlena-v-tomu-shobdoluchitisya-do-iniciativi-58561. Accessed 7 June 2021.

Priority Interconnection Projects 2019 Status Report. Three Seas Initiative, Slovenia, 5-6 June 2019, https://www.three.si/progress-report. Accessed 21 June 2021.

"Przełomowy kontrakt dla PGNiG. Do Polski trafi gaz z USA." Business Insider Polska, 21 Nov. 2017, https://businessinsider.com.pl/firmy/sprzedaz/pgnig-kupowacbedzie-gaz-w-usa/klcnw4m. Accessed 7 June 2021. 
"Remarks by President Trump at the Three Seas Initiative Summit, July 6, 2017." Global Public Affairs, U.S. Department of State, https://2017-2021translations.state.gov/2017/07/06/remarks-by-president-trump-at-the-threeseas-initiative-summit-july-6-2017/index.html. Accessed 21 June 2021.

Rocznik Statystyczny Handlu Zagranicznego 2016 / Yearbook Trade of Foreign Statistics of Poland 2016. GUS, 2016, https://stat.gov.pl/en/topics/statisticalyearbooks/statistical-yearbooks/yearbook-of-foreign-trade-statistics2016,9,10.html. Accessed 21 June 2021.

Rocznik Statystyczny Handlu Zagranicznego 2018 / Yearbook Trade of Foreign $\begin{array}{llll}\text { Statistics of } & \text { Poland }\end{array}$ https://stat.gov.pl/files/gfx/portalinformacyjny/en/defaultaktualnosci/3328/ 9/12/1/yearbook_of_foreign_trade_statistics_of_poland_2018.pdf. Accessed 21 June 2021.

Rotaru, Vasile, and Andreas Umland. "How Romania and Poland Can Strengthen NATO and the EU: Two New Cooperation Initiatives Could Improve Regional Security." Foreign Affairs, 10 Nov. 2017, https://www.foreignaffairs.com/articles/central-europe/2017-11-10/howromania-and-poland-can-strengthen-nato-and-eu. Accessed 7 June 2021.

"Russia's Involvement in the Tallinn Disturbances." World Security Network, 12 May 2007, http://www.worldsecuritynetwork.com/Europe/International-Centrefor-Defence-Studies/Russia\%E2\%80\%99s-Involvement-in-the-TallinnDisturbances. Accessed 7 June 2021.

Sadecki, Andrzej, et al. "Europa Środkowa i Południowo-Wschodnia wobec projektu Nord Stream 2.” Analizy OSW, 14 Oct. 2015, https://www.osw.waw.pl/pl/publikacje/analizy/2015-10-14/europasrodkowa-i-poludniowo-wschodnia-wobec-projektu-nord-stream-2. Accessed 7 June 2021.

Shotter, James. "Three Seas Seeks to Turn Tide on East-West Divide." Financial Times, 22 Nov. 2018, https://www.ft.com/content/2e328cba-c8be-11e8-86e619f5b7134d1c. Accessed 7 June 2021.

Siedlecka, Sylwia, and Marcin Sułkowski. "[Response to] Ankieta Arkanów: Ekonomiczne i kulturowe podstawy Trójmorza." Arcana. Kultura, Historia, Polityka, vol. 5, no. 137, 2017, pp. 36-39.

Sienkiewicz, Marcin. “Koncepcja Trójmorza w polityce zagranicznej Polski po 2015 r." Dyplomacja i Bezpieczeństwo, vol. 1, no. 4, 2016, pp. 139-51.

Sobczyk, Kamil. "Współpraca ośrodków prezydenckich państw wschodniej flanki NATO w toku przygotowań do szczytu Sojuszu w Warszawie." Bezpieczeństwo Narodowe, nos. I-IV, 2016, pp. 51-66, https://www.bbn.gov.pl/ftp/dok/03/3740 KBN Sobczyk.pdf. Accessed 7 June 2021.

Sprawozdanie z działalności prezesa Urzędu Regulacji Energetyki w 2020 r. Urząd Regulacji Energetyki, Apr. 2021, https://bip.ure.gov.pl/download/3/13451/Sprawozdanie2020.pdf. Accessed 22 June 2021.

Stearns, Jonathan. "EU Reaches Deal on New Gas Law with Nord Stream 2 Loopholes.” Bloomberg, 13 Feb. 2019, https://www.bloomberg.com/news/articles/201902-12/eu-gets-deal-on-new-natural-gas-law-with-nord-stream-2-loopholes. Accessed 7 June 2021. 
Stępniewski, Tomasz. "Inicjatywa Trójmorza: uwarunkowania geopolityczne i nowy model regionalnej współpracy." Studia Europejskie, no. 2, 2018, pp. 33-43.

Stoica, Adrian. "Focus on LNG: Constanta Port, a Transit Hub for Europe." Petroleum Industry Review, no 76, Feb. 2015, p. 51, https://issuu.com/petroleumindustryreview/docs/petroleum industry revie w_no 74-75. Accessed 7 June 2021.

"Sukces polityki energetycznej Polski. PGNiG kupi gaz z USA-znacznie tańszy niż rosyjski!" Niezalezna.pl, 17 Oct. 2018, https://niezalezna.pl/240962-sukcespolityki-energetycznej-polski-pgnig-kupi-gaz-z-usa-znacznie-tanszy-nizrosyjski. Accessed 7 June 2021.

Szczerski, Krzysztof. Utopia Europejska. Kryzys integracji i polska inicjatywa naprawy. Wydawnictwo Biały Kruk, 2017.

Szeptycki, Andrzej. "Stosunki pomiędzy Federacją Rosyjską i Ukrainą w sektorze gazowym." Geopolityka rurociagów: Współzależność energetyczna a stosunki międzypaństwowe na obszarze postsowieckim, edited by Ernest Wyciszkiewicz, PISM, 2008, pp. 97-135.

---. Ukraina wobec Rosji. Studium zależności. Wydawnictwa Uniwersytetu Warszawskiego, 2013.

Szőcs, László. “Hungary Didn't Block Ukraine's New Special NATO Status.” REMIX, 18 June 2020, https://rmx.news/article/article/hungary-didn-t-block-ukraine-snew-special-nato-status. Accessed 7 June 2021.

Szymajda, Michał. "Ukraińskie Koleje uruchomią codzienny pociąg PrzemyślOdessa." Rynek Kolejowy/inf. Prasowa, 18 Oct. 2017. http://www.rynekkolejowy.pl/wiadomosci/ukrainskie-koleje-uruchomia-codzienny-pociagprzemysl--odessa-83996.html. Accessed 7 June 2021.

Terlikowski, Marcin. "Ataki elektroniczne na Estonię. Implikacje dla bezpieczeństwa międzynarodowego i Polski." Polski Przegląd Dyplomatyczny, vol. 7, no. 4 (38), 2007, pp. 53-74.

The Joint Statement on the Three Seas Initiative (The Dubrovnik Statement). 25 Aug. 2016, http://three-seas.eu/wp-content/uploads/2018/06/DUBROVNIK.pdf. Accessed 21 June 2021.

"The Three Seas Initiative: Central and Eastern Europe Takes Charge of Its Own Destiny." Visegrád Post, 28 Aug. 2016, https://visegradpost.com/en/2016/08/28/the-three-seas-initiative-centraland-eastern-europe-takes-charge-of-its-own-destiny/. Accessed 7 June 2021.

Torsti, Pilvi. Why Do History Politics Matter? The Case of the Estonian Bronze Soldier. The Cold War and the Politics of History. University of Helsinki Department of Social Science History, 2008.

"Transeuropejska sieć transportowa-TEN-T." Gov.pl: Website of the Republic of Poland, https://www.gov.pl/web/infrastruktura/transeuropejska-siectransportowa-ten-t. Accessed 7 June 2021.

"Trójmorze." Ministry of Foreign Affairs, Republic of Poland, https://www.gov.pl/web/dyplomacja/trojmorze. Accessed 21 June 2021.

"UE ma wesprzeć finansowanie budowy trasy Odessa-Gdańsk." Forsal.pl, 21 Feb. 2018, https://forsal.pl/artykuly/1105966,ue-ma-wesprzec-finansowaniebudowy-trasy-odessa-gdansk.html. Accessed 7 June 2021. 
Ukielski, Paweł. "Inicjatywa Trójmorza w polskiej polityce zagranicznej." Studia Europejskie, vol. 2, no. 86, 2018, pp. 45-58.

Vaughan, Adam. "Nord Stream 2 Russian Gas Pipeline Likely to Go Ahead after EU Deal." The Guardian, 25 Feb. 2019, https://www.theguardian.com/business/2019/feb/25/nord-stream-2russian-gas-pipeline-likely-to-go-ahead-after-eu-deal. Accessed 7 June 2021.

"Via Baltica. W tym roku sześć odcinków, m.in. Raczki - Wysokie, a Suwałki - Budzisko za rok." Suwałki 24.pl, 13 Mar. 2021, https://www.suwalki24.pl/article/34,viabaltica-w-tym-roku-szesc-odcinkow-min-raczki---wysokie-a-suwalki--budzisko-za-rok-. Accessed 21 June 2021.

"Via Carpatia powinna być gotowa w 2024 r." Onet, 5 Jan. 2018, https://moto.onet.pl/aktualnosci/via-carpatia-powinna-byc-gotowa-w-2024r/sm9kz9c. Accessed 7 June 2021.

Views and News. Newsletter of the Office of the President of the Republic of Croatia, no. 2, Dec. 2015, pp. 1-21.

“W Łańcucie podpisano III Deklarację Via Carpatia." PolUkr: pol's'ko-ukrains'kyi portal, 2019, http://www.polukr.net/blog/2019/04/w-lancucie-podpisano-iiideklaracje-via-carpatia/. Accessed 21 June 2021.

Wójtowicz, Paulina. "Rail Baltica: Finlandia chce przyspieszenia budowy linii kolejowej." inzynieria.com, 3 Dec. https://inzynieria.com/drogi/wiadomosci/54317,rail-baltica-finlandia-chceprzyspieszenia-budowy-linii-kolejowej. Accessed 7 June 2021.

"Wspólnym głosem w Łańcucie o trasie Via Carpatia." Generalna Dyrekcja Dróg $\begin{array}{lllll}\text { Krajowych } & i & \text { Autostrad, } & 17 & \text { April }\end{array}$ https://www.gddkia.gov.pl/pl/aprint/33200/Wspolnym-glosem-w-Lancucieo-trasie-Via-Carpatia. Accessed 7 June 2021.

Wyciszkiewicz, Ernest. "Rosyjski sektor naftowo-gazowy-uwarunkowana wewnętrzne i perspektywy rozwoju." Geopolityka rurociagów: Współzależność energetyczna a stosunki międzypaństwowe na obszarze postsowieckim, edited by Ernest Wyciszkiewicz, PISM, 2008, pp. 5-55.

Zbińkowski, Grzegorz. "The Three Seas Initiative and Its Economic and Geopolitical Effect on the European Union and Central and Eastern Europe." Comparative Economic Research, vol. 22, no. 2, 2019, pp. 105-119. DOI: 10.2478/cer-20190015

"Zelensky: Ukraine Interested in Joining Three Seas Initiative." Kyiv Post, 1 Sept. 2019, https://www.kyivpost.com/ukraine-politics/zelensky-ukraine-interested-injoining-three-seas-initiative.html?cn-reloaded=1. Accessed 7 June 2021.

Żornaczuk, Tomasz. “Three Seas Completed by 2025?” Biznes Alert, 14 July 2017, http://biznesalert.com/zornaczuk-three-seas-completed-2025/. Accessed 7 June 2021.

Żurawski vel Grajewski, Przemysław. The Eastern Policy of Poland: EU and National Perspective 1989-2015. CEN, 2017.

---. "La nuova Europa longitudinale: il Trimarium visto dalla Polonia." Limes. Rivista Italiana di Geopolitica: Trimarium tra Russia e Germania, no. 12, 2017, pp. 10714.

---. Polityka Unii Europejskiej wobec Rosji a interesy Polski 1991-2004. Ośrodek Myśli Politycznej, 2008. 
---. “Specyfika relacji polsko-ukraińskich po 2015 r.” Sprawy Międzynarodowe, no. 1, 2018, pp. 41-92.

---. "Trimarium: A View from the North." Adriatic-Baltic-Black Sea Visions of Cooperation, edited by Kinga Redłowska, Institute for Eastern Studies, 2017, pp. 8-20.

---. "Trójmorze w grze w trójkącie USA-Rosja-Chiny." Portal Trójmorze, 10 March 2021, https://trimarium.pl/przemyslaw-zurawski-vel-grajewski-trojmorze-wgrze-w-trojkacie-usa-rosja-chiny/. Accessed 7 June 2021.

---. "Unia Europejska wobec rosyjsko-ukraińskiego sporu gazowego kwiecieńpaździernik 2014 r." Międzynarodowe studia polityczne $i$ kulturowe wobec wyzwań współczesności, edited by Tomasz Domański, Wydawnictwo Uniwersytetu Łódzkiego, 2016, pp. 199-226.

---. "V Szczyt Trójmorza w Tallinie." Portal Trójmorze, 10 March 2021, https://trimarium.pl/profesor-przemyslaw-zurawski-vel-grajewski-v-szczyttrojmorza-w-tallinie/. Accessed 7 June 2021. 